\title{
MEDICAL STUDENTS' REFLECTION ON CHEATING, ALTRUISM AND PLAGIARISM: A QUALITATIVE STUDY
}

\author{
Wiwik Kusumawati*, Titi Savitri Prihatiningsih**, Gandes Retno Rahayu**, Soenarto Sastrowijoto** \\ * Fakultas Kedokteran dan IImu Kesehatan Universitas Muhammadiyah Yogyakarta, Yogyakarta - INDONESIA \\ ** Fakultas Kedokteran, Kesehatan Masyarakat dan Keperawatan Universitas Gadjah Mada, Yogyakarta - INDONESIA
}

\begin{abstract}
Background: Derogation of professional behavior (PB) increased in education, even in medical education revealed cheating during in educational process as best predictor when the students at work placed in the future. The aim of this study is to know the students' perspective on cheating, altruism and plagiarism.
\end{abstract}

Method: This study was conducted using a qualitative approach. Sampling technique was purposeful sampling with criterion reference. Fifty-two year-one students of medical school of faculty of medicine and health sciences (FMHS) divided into 5 groups, each group consists of 10 to 11 students. The students received teaching learning of PB (three times tutorial with trigger film, reflection and expert panel). Qualitative data from students' reflection analized using constant comparative method.

Results: The results of this study indicated the presence of 6 final themes (i.e., learning value, learning approach, student preparedness, examination strategy, learning spiritual, study plan. Students who had the ability to understand various learning events would have a good study plan, and then could choose appropriate examination strategy to reach success and could avoid blamable event such as cheating. The students who had good learning spiritual and learning value to dilemmatic event, they would be motivated and their heart would be touched, so in their future plan they would try to be altruistic and professional doctor in all situation. There would be influence on positive study plan, make more effort and pried to God, also respect others work, so plagiarism could be avoided.

Conclusion: There were 6 final themes of students' reflection on cheating, altruism and plagiarism after they exposure by teaching learning of $\mathrm{PB}$. They were learning value, learning approach, student preparedness, examination strategy, learning spiritual and study plan.

Keywords: Professional Behavior, Qualitative, Cheating, Altruism, Plagiarism

\begin{abstract}
ABSTRAK
Latar belakang: Kejadian pelanggaran perilaku profesional (PP) ditengarai semakin meningkat dalam pendidikan, bahkan studi pada profesi dokter menunjukkan bahwa cheating pada masa pendidikan merupakan best predictor pada waktu mahasiswa lulus dan bekerja. Penelitian ini dilakukan untuk mendapatkan gambaran perspektif mahasiswa terhadap 3 atribut PP, yaitu: cheating, altruism dan plagiarism.

Metode: Penelitian ini menggunakan pendekatan kualitatif. Pemilihan sampel secara purposive dengan criterion reference. Lima kelompok tutorial mahasiswa tahun pertama program studi pendidikan dokter FKIK UMY masing-masing terdiri dari 10 sd 11 mahasiswa dipilih secara acak $(n=52)$ dan mendapat intervensi pembelajaran PP dengan tiga kali tutorial trigger film, refleksi dan panel ahli. Data hasil refleksi mahasiswa tentang cheating, plagiarisme dan altruisme dianalisis secara kualitatif dengan constant comparative method. Hasil: Hasil penelitian menunjukkan 6 tema final, yaitu: 1) Learning value; 2) Learning approach; 3) Student preparedness; 4) Examination strategy; 5) Learning spiritual; dan 6) Study plan. Seseorang dengan kemampuan
\end{abstract}

contact: wiwik_fk_umy@yahoo.com.sg 
memaknai suatu peristiwa dan dapat mengambil nilai positif akan mempunyai perencanaan belajar (study plan) yang baik, sehingga dapat memilih strategi menghadapi ujian (examination strategy) yang tepat untuk meraih keberhasilan dan menghindari perbuatan tercela seperti cheating. Seseorang dengan learning spiritual dan learning value yang baik terhadap peristiwa dilematis akan termotivasi dan tersentuh emosinya, sehingga dalam future plannya akan berusaha menjadi dokter yang altruis dan profesional dalam situasi apapun. Dalam study plan lebih bersungguh-sungguh dalam berusaha dan berdoa kepada Allah, SWT serta mampu menghargai hasil karya orang lain, sehingga terhindar dari berbagai bentuk tindak plagiat.

Kesimpulan: Hasil analisis kualitatif refleksi mahasiswa tentang cheating, altruism dan plagiarism setelah mereka terpapar dengan pembelajaran PP menunjukkan 6 makna final, yaitu: 1) Learning value; 2) Learning approach; 3) Student preparedness; 4) Examination strategy; 5) Learning spiritual; dan 6) Study plan.

Kata kunci: Perilaku Profesional (PP), Kualitatif, Cheating, Altruism, Plagiarism

\section{PENDAHULUAN}

Pengembangan karakter, sifat dan perilaku yang berhubungan dengan profesionalisme menjadi area penting dalam pendidikan dokter untuk melengkapi kompetensi kognitif dan psikomotor sesuai dengan tujuan yang diharapkan. ${ }^{1,2}$ Salah satu tugas dokter adalah memberikan pelayanan kesehatan kepada masyarakat. Pelayanan pasien yang baik tidak hanya tergantung pada kompetensi kognitif dan psikomotor saja, tetapi juga membutuhkan kompetensi afektif atau perilaku profesional. ${ }^{3}$ Kurangnya kompetensi dokter dalam perilaku profesional (PP) disebabkan oleh pendidikan dokter selama ini lebih menekankan pada pengajaran kognitif dan psikomotor. Kompetensi afektif, meskipun penting belum diajarkan secara eksplisit dan dinilai secara valid dan sistematis. ${ }^{4,5}$

Kejadian cheating pada mahasiswa di perguruan tinggi menunjukkan angka yang tinggi, dengan variasi antara $30 \%$ sampai dengan $96 \%$. Menurut American Council on Higher Education, cheating semakin meningkat dengan variasi antara 40\% sampai dengan $80 \%$. Cheating yang dilakukan dalam pendidikan dokter di perguruan tinggi, ternyata juga pernah dilakukan pada pendidikan sebelumnya di SMA. Hal ini menunjukkan bahwa perilaku (cheating) pada masa pendidikan akan terbawa sampai pada waktu mahasiswa bekerja dan hal ini dapat merugikan institusi tempat kerja. Studi pada profesi dokter menunjukkan bahwa cheating merupakan best predictor, dishonesty yang dilakukan pada waktu menjadi mahasiswa di perguruan tinggi juga menyebabkan dishonesty pada waktu bekerja. ${ }^{6,7}$

Studi yang pernah dilakukan oleh Kusumawati ${ }^{8}$ tentang profesionalisme dan perilaku profesional (PP) mahasiswa pada Program Studi Pendidikan Dokter menunjukkan bahwa kejujuran terutama dalam ujian merupakan salah satu nilai atau atribut PP yang masih perlu diperbaiki selain care terhadap orang lain, fasilitas belajar dan berbusana muslim/ muslimah yang baik (appearance). Hal ini sesuai dengan studi yang dilakukan oleh Erhamwilda, ${ }^{9}$ bahwa ketidakjujuran dalam pendidikan, seperti pemalsuan nilai, ijazah, kenaikan kelas yang dipaksakan masih merupakan salah satu problem utama pendidikan di Indonesia.

Altruisme merupakan salah satu atribut PP yang penting bagi profesi dokter terutama dalam menjalankan tugas profesinya untuk menangani pasien. Perilaku altruis merupakan tujuan pertama dalam pendidikan dokter di era global, sehingga mengajarkan dan menilai perilaku ini secara formal sangatlah penting. Informasi tentang metode yang efektif dan penilaian altruisme masih terbatas dilakukan oleh peneliti sebelumnya. Penelitian kualitatif tentang cheating, altruism dan plagiarism ini dilakukan untuk mendapatkan gambaran perspektif dan pemikiran mahasiswa terhadap 3 atribut perilaku profesional (PP) tersebut setelah mereka terpapar dengan pembelajaran cheating, altruism dan plagiarism. 


\section{METODE}

Penelitian ini menggunakan pendekatan kualitatif. Pemilihan sampel secara purposive dengan criterion reference. ${ }^{10,11}$ Sampel penelitian menggunakan mahasiswa kedokteran tahun pertama. Menurut Goldie et al. ${ }^{12}$ pengembangan disain kurikulum profesionalisme pada awal tahun pendidikan dapat memberikan kesempatan bagi mahasiswa untuk mengembangkan pengetahuan yang dibutuhkan untuk praktik profesional. Mahasiswa yang menjadi responden sudah mendapatkan informed consent. Penelitian ini juga sudah memenuhi kelayakan etik dari komisi etik penelitian Fakults Kedokteran UGM.

Lima kelompok tutorial mahasiswa tahun pertama program studi pendidikan dokter FKIK UMY dipilih secara acak menjadi kelompok perlakuan $(n=52)$. Masing-masing kelompok terdiri dari sekitar sepuluh sampai dengan sebelas orang. Kelompok perlakuan ini mendapatkan perlakuan intervensi pembelajaran PP yang terdiri dari tiga kali tutorial trigger film, masing masing disertai refleksi dan satu kali panel ahli. Film sebagai trigger pembelajaran bermuatan spiritual dan religi, demikian pula panel ahli. Tiga Film berdurasi 10 sampai dengan 15 menit secara berurutan berisi tentang mahasiswa menyontek waktu sedang ujian (cheating), dokter muda waktu tugas jaga di rumah sakit mendapatkan berita ayahnya sakit dan meninggal (altruism) dan plagiasi waktu mengerjakan skripsi (plagiarism). Skenario film dan pembuatan film secara kualitatif direview oleh ahli (supervisor), dosen dan peneliti tentang keseuaian konten film dengan tujuan pembelajaran.

Tutorial atau diskusi kelompok dilakukan tiga kali masing-masing berdurasi sekitar dua jam menggunakan film sebagai trigger. Tutorial difasilitasi oleh seorang tutor yang dipilih berdasarkan kriteria sudah pernah mengikuti training of tutor (TOT). Film berdurasi sekitar lima belas menit berisi tentang cheating, plagiarisme dan altruisme. Setelah melihat film, setiap mahasiswa diminta untuk membuat refleksi tentang film yang sudah dilihat dan kemudian mendiskusikan hasil refleksinya. Refleksi menggunakan form dari Gibbs yang berisi tentang deskripsi film, perasaan setelah melihat film, evaluasi (hal yang baik dan buruk tentang isi film), analisis (pikiran terhadap isi film), kesimpulan (yang sebaiknya dilakukan dan tidak dilakukan) dan rencana tindak lanjut.

Data hasil 3 refleksi mahasiswa tentang cheating, plagiarisme dan altruisme masing-masing dianalisis secara kualitatif. Prosedur analisis data kualitatif meliputi unitizing atau pemaknaan, kategorisasi, constant comparative method dan connecting categories atau menghubungkan antar kategori. ${ }^{13,14}$ Unitizing atau pemaknaan, data yang sudah didapatkan dari refleksi mahasiswa dicari maknanya dan diberi kode. Dalam kategorisasi, makna yang sudah dikumpulkan pada tahap sebelumnya dikelompokkan atau dikategorikan berdasarkan kemiripan makna. Selanjutnya dengan constant comparative method, kategori atau tema yang sudah disusun dibaca lagi berulang-ulang, sehingga kategorisasi dapat diperluas bila ditemukan kategori baru atau bahkan digabung bila ada kesamaan makna. Pada connecting categories atau menghubungkan antar kategori, biasanya pada tahap akhir analisis kualitatif akan didapatkan sekitar lima sampai dengan sepuluh kategori yang dinamakan kategori final. Kategori final ini kemudian dianalisis, dicari hubungan satu sama lain, sehingga menjadi penjelasan yang logis dan komprehensif. Hasil analisis kualitatif yang dilakukan oleh peneliti kemudian diverifikasi oleh supervisor.

\section{HASIL DAN PEMBAHASAN}

Setelah dilakukan analisis kualitatif pada hasil refleksi mahasiswa tentang cheating, altruism dan plagiarism didapatkan gambaran makna final seperti pada Gambar 1. 


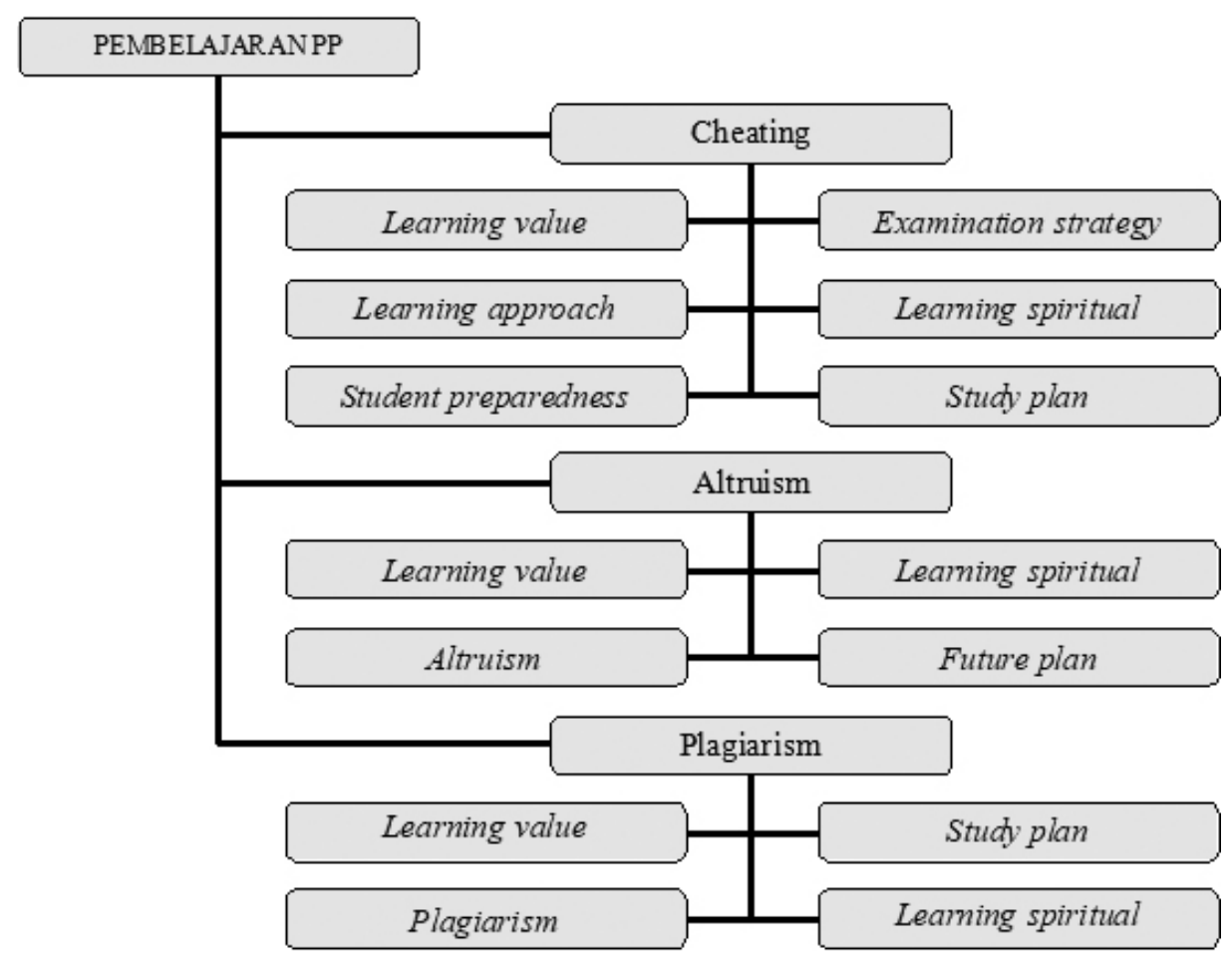

Gambar 1. Diagram makna final pembelajaran perilaku profesional (PP)

\section{Refleksi cheating}

Pada refleksi tentang cheating ini, setelah dilakukan analisis kualitatif dan verifikasi, didapatkan beberapa makna atau kategori final, yaitu: 1) Learning value; 2) Learning approach; 3) Student preparedness; 4) Examination strategy; 5) Learning spiritual; dan 6) Study plan.

Learning value mempunyai arti, yaitu hal-hal atau sifat yang bermanfaat untuk menjadikan seseorang belajar. Hal-hal atau sifat tersebut dapat bersifat positif maupun negatif, artinya seseorang dalam menyikapi suatu kejadian dan peristiwa dapat baik atau positif dan sebaliknya kurang baik atau negatif. Berikut ini beberapa pernyataan mahasiswa yang berhubungan dengan learning value.

"prihatin melihat mahasiswa yang malas belajar, dia lebih mementingkan bermain PS daripada mempersiapkan diri menghadapi ujian. Prihatin melihat mahasiswa yang menyontek saat ujian berlangsung". (I.1)

"film ini mengangkat kasus-kasus yang sering terjadi di kalangan pelajar/mahasiswa di Indonesia.
Sebagai seorang pelajar/mahasiswa, kita harus sadar agar tidak terjerumus dalam perbuatan yang salah". (I.20)

Learningapproach merupakan kegiatan yang dilakukan oleh mahasiswa pada proses belajar dan alasan mereka melakukan. Pendekatan pembelajaran dapat berbeda antara individu satu dengan individu lain. Pendekatan pembelajaran seseorang dapat bersifat mendalam (deep learning), yaitu belajar dengan menekankan pada understanding dan critical analysis. Pendekatan pembelajaran juga dapat superfisial atau lebih cenderung menghafal (remembering). Pendekatan pembelajaran yang dilakukan oleh mahasiswa juga dapat sungguh sungguh, tetapi ada pula yang santai atau bersenang-senang atau bahkan bermalas-malasan. Berikut ini pernyataan mahasiswa yang berhubungan dengan learning approach.

"terdapat 2 kepribadian mahasiswa dalam menghadapi ujian ada yang mempersiapkan diri dengan belajar yang tekun sedangkan mahasiswa yang satunya lebih memilih bermain/tidak belajar". (I.1) 
Student preparedness dalam belajar atau ujian ada yang sangat baik, cukup dan tidak baik. Mahasiswa dengan persiapan yang sangat baik menyadari betul tugas dan kewajiban serta konsekuensi apabila dia lalai atau meremehkan. Sebaliknya, mahasiswa dengan persiapan yang tidak baik memiliki rasa tanggung jawab yang kurang dan lebih mengutamakan kesenangan. Berikut ini beberapa pernyataan mahasiswa yang berhubungan dengan student preparedness.

"Ketika menjadi seorang mahasiswa, kita seharusnya dapat memiliki time management yang baik, membagi waktu antara bermain dan belajar. Kita harus mempersiapkan diri sebaik-baiknya ketika hendak menghadapi ujian dan ketika ujian berlangsung kita harus percaya diri akan jawaban yang kita berikan tanpa melakukan tindakan tercela seperti menyontek". (I.1)

"Melakukan time management yang baik akan membuat hidup kita teratur dan tertata. Jangan suka menyepelekan sesuatu. Menghargai orangorang di sekeliling kita seperti orang tua. Mereka selalu mendoakan dan mengharapkan yang terbaik dari kita". (I.16)

Examination strategy adalah cara atau strategi mahasiswa dalam menghadapi ujian. Strategi ujian mahasiswa ada yang baik dan buruk. Contoh yang baik yaitu belajar dengan sungguh-sungguh, mengatur waktu dengan baik, sholat tepat waktu, mengaji, datang tepat waktu, dll. Strategi yang tidak baik adalah tidak belajar, bermain, terlambat datang ujian, dan menyontek. Berikut ini pernyataan mahasiswa yang berhubungan dengan examination strategy.

"hal yang baik yaitu belajar untuk persiapan ujian, sholat tepat waktu, mengaji, datang ke kampus sebelum ujian dan meminta pertolongan Allah (berdoa). Hal yang buruk yaitu bermain game berlebihan, tidak belajar, tidak sholat 5 waktu, datang ujian telat, menyontek....". (I.5)

"mahasiswa A mempunyai time management yang bagus, belajar tepat waktu, beribadah tepat waktu, disiplin. Hal yang buruk yaitu bermain sampai pagi, datang terlambat, menyontek saat ujian, tidak belajar". (I.11)

Learning spiritual, menurut Kamus Besar Bahasa Indonesia (KBBHI, 1998) ${ }^{15}$ spiritual berarti batin atau rohani, arti lain spiritual, yaitu proses atau kemampuan seseorang memaknai suatu kejadian dan peristiwa, dalam hal ini terhadap proses pembelajaran. Learning spiritual seseorang dapat kuat dan lemah. Seseorang dengan learning spiritual yang kuat, apabila melihat suatu kejadian atau peristiwa dapat memaknai atau mengambil hikmah positif untuk kehidupannya. Sebaliknya seseorang dengan learning spiritual yang lemah, tidak mampu memaknai secara positif terhadap suatu kejadian atau peristiwa. Berikut ini pernyataan mahasiswa yang berhubungan dengan learning spiritual.

"mengingatkan jangan terbuai duniawi, belajar dengan rajin dan menerapkan ke kehidupan dan mengingat bahwa azab Allah pedih bila kita meninggalkan tugas-tugas kita ......". (I.32)

"Sikap menyontek sebaiknya tidak dibudidayakan. Mahasiswa pencontek harus menyadari akan tanggung jawabnya. Ia harusnya dapat memilahmilah mana yang harusnya dilakukan dan yang tidak dilakukan. Mahasiswa tersebut harusnya tidak melupakan kewajibannya kepada Tuhan, karena sifat buruk pasti berasal dari kebiasaan buruk". (I.44)

Study plan, rencana studi berikutnya pada seseorang dapat sangat ideal atau tinggi dan rendah. Rencana ke depan mahasiswa untuk studinya mulai dari ideal, yaitu adanya niat atau motivasi tinggi meraih keberhasilan dengan usaha yang maksimal tanpa melakukan atau menghindari perbuatan tercela seperti menyontek. Sebaliknya, rencana ke depan mahasiswa untuk studinya yang rendah berarti tidak ada niat atau motivasi untuk meraih keberhasilan atau kesuksesan. Berikut ini beberapa pernyataan mahasiswa yang berhubungan dengan study plan.

"Saya akan menyiapkan segala sesuatunya jika ujian tiba, seperti belajar, tetap berdoa kepada Allah SWT., dan jika tidak dapat mengerjakan 
ujian, saya tidak akan menyontek karena apapun yang kita lakukan dilihat oleh Allah SWT". (I.29)

"yang selanjutnya akan saya lakukan adalah mengatur waktu dengan baik dan menerapkan kehidupan yang teratur serta menanamkan nilainilai kejujuran". (I.5)

"hal yang akan saya lakukan adalah membatasi waktu bermain untuk belajar, juga tidak melewatkan sholat wajib dan membaca Al Qur'an. Juga saat ujian tidak berbuat curang......". (I.19)

Dengan melihat film tentang cheating, mahasiswa mendapatkan nilai positif bahwa peristiwa yang dilihat di film menyentuh sampai tingkat emosi mereka, sehingga timbul perasaan kasihan, iba, jengkel dan sudah sepantasnya mahasiswa yang menyontek mendapatkan hukuman yang setimpal. Mahasiswa dapat mengambil hikmah atau makna dari dua kejadian, yaitu satu mahasiswa sungguhsungguh belajar dan beribadah, sementara mahasiswa yang lain bermalas-malasan hanya dengan bermain play station (PS) dan terlambat datang ujian.

\section{Refleksi altruisme}

Hasil refleksi mahasiswa tentang altruisme juga dianalisis dengan constant comparative method dan verifikasi, sehingga didapatkan beberapa kategori makna final, yaitu: 1) Learning value; 2) Altruism; 3) Learning spiritual; dan 4) Future plan.

Learning value yaitu hal-hal yang bermanfaat untuk menjadikan seseorang belajar. Hal-hal atau sifat tersebut dapat positif maupun negatif, artinya seseorang dalam menyikapi suatu kejadian dan peristiwa dapat baik atau positif dan sebaliknya kurang baik atau negatif. Mahasiswa menyatakan bahwa kejadian di film merupakan peristiwa yang dilematis, langka atau sulit, namun patut dicontoh atau dijadikan model. Tokoh di film menimbulkan rasa kekaguman serta bangga bagi yang melihat seperti dinyatakan oleh beberapa responden berikut.

"Saya sangat terinspirasi oleh dokter muda yang ada di film ini karena dia rela berkorban meskipun ia sendiri dalam keadaan yang kurang baik dan ada masalah pribadi ...". (II.5)

“... sikap ketegaran dan profesionalisme dari seorang dokter. Saya belajar bagaimana seharusnya yang dilakukan ketika dihadapkan dengan 2 kondisi seperti itu, sebagai bagian dan konsekuensi menjadi seorang dokter". (II.1)

"Bangga, salut terhadap apa yang dilakukan dokter dan patut ditiru kita sebagai calon dokter ...". (II.37)

Altruisme berarti paham atau sifat yang lebih memperhatikan dan mengutamakan kepentingan orang lain (kebalikan dari egoisme), ${ }^{15}$ sedangkan menurut ABIM, altruisme adalah, "constitutes the essence of professionalism and is based on the rule that the best interest of patients and not self-interest is the professional obligation"

Seseorang dapat memiliki sikap altruis, mementingkan kepentingan orang lain di atas kepentingan pribadi, kebalikan altruis, yaitu egois atau seimbang dalam menempatkan antara kepentingan untuk orang lain dan kepentingan pribadi. Sebagian besar mahasiswa menyatakan bahwa tokoh di film (dokter Rahma) menunjukkan sikap profesional dan altruis. Hal ini dapat dilihat dari pernyataan beberapa responden berikut.

"Dokter Rahma tabah menghadapi masalah, memiliki tekad yang kuat, berlaku profesional walaupun sedang ada masalah, pintar karena kuliahnya dari beasiswa, membantu tanpa pamrih ......". (II.18)

"Dokter tersebut menunjukkan tanggung jawab terhadap profesinya sebagai seorang dokter, melayani pasien sebaik-baiknya, bersikap profesional dalam bekerja walaupun keadaan sedang tidak baik, bersikap baik, ramah dengan tenaga kesehatan lainnya dan mementingkan orang lain". (II.31)

Learning spiritual, spiritual berarti batin atau rohani, arti lain spiritual yaitu proses atau kemampuan seseorang memaknai suatu kejadian dan peristiwa, ${ }^{15}$ dalam hal ini terhadap proses pembelajaran. Learning spiritual seseorang dapat kuat dan lemah. Seseorang 
dengan learning spiritual yang kuat, apabila melihat suatu kejadian atau peristiwa dapat memaknai atau mengambil hikmah positif untuk kehidupannya. Sebaliknya, seseorang dengan learning spiritual yang lemah, tidak mampu memaknai secara positif terhadap suatu kejadian atau peristiwa. Mahasiswa menyatakan bahwa tokoh di film (dokter Rahma) menunjukkan sebagai dokter yang mempunyai semangat atau spirit, tekad yang kuat dalam meraih cita-cita, tenang dalam menghadapi pasien di tengah masalah pribadi yang sulit dan taat beribadah. Hal ini dapat dilihat dari pernyataan beberapa responden berikut.

"Prihatin, bangga, senang dan lebih termotivasi lagi, melihat seorang dokter yang sangat tanggung jawab dalam menghadapi pekerjaan serta begitu sabar, kuat, ikhlas dan tegar dalam menghadapi masalah/cobaan hidup". (II.15)

"Film tadi saya rasa sangat motivatif, di tengah kesedihan/kegundahan seorang dokter masih ada rasa tenang. Hal itu dapat dilihat dari pelayanannya terhadap pasien yang sangat tenang dan tetap semangat untuk bekerja". (II.20; II 17)

Future plan, rencana ke depan pada seseorang dapat sangat ideal atau tinggi dan rendah. Rencana ke depan mahasiswa sebagai calon dokter mulai dari ideal, yaitu adanya niat atau motivasi tinggi untuk menjadi a good doctor dengan atribut-atributnya. Sebaliknya, rencana ke depan mahasiswa sebagai calon dokter yang rendah berarti tidak memahami dan memiliki motivasi untuk menjadi dokter yang baik dan karakteristiknya.

"Saya akan meniru sikap dokter tersebut karena menurut saya itu adalah sikap yang terbaik bagi seorang dokter". (II.11)

".... Saya akan lebih semangat dan sadar diri serta tanggung jawab terhadap apa saja yang ditugaskan, I'll be a good doctor". (II.3)

"Jika Saya dihadapkan seperti pada keadaan seperti apa yang dialami dokter Rahma, saya akan tetap bersikap profesional, tetap ramah, senyum, tanggung jawab pada pasien dan yang lainnya ........ (II.26)
Film tentang altruisme mengisahkan pengalaman dokter muda yang sedang bertugas di perantauan, sementara ayahnya yang tinggal jauh di rumah sedang sakit keras. Ketika dihadapkan pada dua pilihan, yaitu tetap menjalankan tugas atau pulang kampung untuk melihat ayahnya, dokter muda tersebut tetap memilih menjalankan tugasnya menolong pasien di rumah sakit. Menurut pernyataan mahasiswa, peristiwa dalam film sangat dilematis, berat dan sulit. Sebagian besar mereka menyatakan bahwa keputusan dokter untuk tetap bertugas menimbulkan inspirasi dan motivasi bagi mahasiswa sebagai calon dokter, sehingga patut diteladani. Sikap dokter tersebut termasuk langka namun benar dan menimbulkan rasa kagum, bangga, terharu meskipun ada kesedihan melihat masalah pribadinya. Sebagian kecil saja mahasiswa yang menyatakan perlunya keseimbangan dalam memutuskan antara kepentingan tugas dan pribadi atau keluarga.

\section{Refleksi plagiarisme}

Hasil refleksi mahasiswa tentang plagiarisme juga dianalisis dengan constant comparative method dan verifikasi, sehingga didapatkan beberapa kategori makna final, yaitu: 1) Learning value; 2) Plagiarism; 3) Study plan; dan 4) Learning spiritual.

Learning value, mahasiswa mampu mengambil nilai pembelajaran dari suatu peristiwa. Kemampuan yang dimiliki ini bisa positif atau negatif. Positif berarti mahasiswa mampu mengambil nilai atau makna dari suatu kejadian. Negatif berarti tidak mampu menjadikan paparan pengalaman atau peristiwa sebagai proses pembelajaran. Sebagian besar mahasiswa menunjukkan kemampuan atau learning value yang positif seperti pada beberapa pernyataan responden berikut.

"Menurut pendapat saya, film tadi banyak memberikan pesan-pesan kepada kita, mengenalkan kepada kita betapa pentingnya nilainilai kejujuran itu untuk meraih kesuksesan baik di dunia maupun akhirat, serta mengajarkan nilai tanggung jawab kepada kita". (III.18)

"Menurut pendapat saya, ketika melihat situasi tersebut adalah adanya degradasi moral mahasiswa. 
Mereka mengandalkan berbagai cara untuk mengejar deadlinenya tanpa mempertimbangkan baik buruk serta efek yang dihasilkan. Meskipun niatnya baik tapi semua tergantung prosesnya, apabila prosesnya tidak baik maka pasti hasilnya pasti tidak baik". (III.40)

Plagiarisme berarti penjiplakan yang melanggar hak cipta, Sedangkan plagiat adalah pengambilan karangan atau pendapat orang lain dan menjadikannya seolah-olah karangan atau pendapatnya sendiri. ${ }^{15}$ Menurut Cameron et al. ${ }^{16}$ plagiarisme didefinisikan sebagai as using another author's material or ideas without proper attribution. Plagiarisme merupakan perbuatan ilegal karena melanggar hak cipta, baik disengaja maupun tidak. Plagiarisme termasuk cheating. Definisi cheating menurut Mayville cit Cullen ${ }^{17}$ yaitu, "being dishonest, implying a fraudulent practice or use of trickery whereby individuals submit works of others as their own".

Mahasiswa menyatakan bahwa plagiarisme merupakan perbuatan yang salah dan sering dilakukan oleh mahasiswa karena berbagai sebab. Hal ini dapat dilihat pada beberapa pernyataan responden berikut.

"Menurut saya, plagiarisme adalah tindakan yang sangat buruk, apalagi untuk yang sudah tahap mahasiswa. Hal ini benar-benar mencoreng nama dirinya sendiri (yang melakukan plagiarisme) dan pendidikan di Indonesia". (III.31)

"... cerminan mahasiswa ataupun pelajar saat ini. Banyak anak-anak muda yang dalam pengerjaan tugasnya hanyalah menyalin dari web ke web di internet dan mereka tidak paham betul akan materi yang ditugaskan". (III.27)

Study plan, perencanaan belajar seseorang dalam studi dapat baik atau buruk. Perencanaan belajar yang baik, antara lain dapat mengatur waktu dengan baik, tertib atau disiplin, belajar sungguh-sungguh, dll. Hal ini dapat dilihat pada beberapa pernyataan responden berikut. Perencanaan belajar yang buruk tentunya sebaliknya, yaitu tidak dapat mengatur waktu dengan baik, tidak disiplin, sehingga pada saat ada dead line tugas berbuat yang tidak terpuji yaitu plagiat atau menyontek. Berikut beberapa pernyataan mahasiswa yang berhubungan dengan study plan.

"Saya akan berusaha untuk fokus dalam perkuliahan mulai dari awal semester sampai akhir semester. Selain itu, mempersiapkan segala tugas termasuk KTI dengan baik. Kemudian saya akan mengharamkan segala bentuk plagiarisme, karena selain membohongi diri sendiri hal tersebut merupakan praktek melanggar hukum". (III.11)

"Selalu tertib dengan waktu, menyelesaikan tugas dengan baik, menghargai hasil karya orang lain, sehingga ketika mau mengutip sesuatu harus menuliskan sumbernya, .... memprioritaskan skripsi, mengatur waktu untuk menyelesaikan skripsi, persiapan matang untuk sidang skripsi, tetap sholat dan berdoa kepada Allah".". (III.29)

Learning spiritual, learning artinya pembelajaran. Spiritualitas atau spiritualisme berasal dari kata spiritual yang berarti berhubungan dengan atau bersifat kejiwaan (rohani, batin). ${ }^{15}$ Spiritual juga berarti kemampuan memaknai kehidupan atau peristiwa. Kemampuan memaknai yang dimiliki ini bisa positif atau negatif. Positif berarti seseorang mampu mengambil nilai atau makna dari suatu kejadian. Negatif berarti tidak mampu menjadikan paparan pengalaman atau peristiwa sebagai proses pembelajaran. Pernyataan responden berikut sebagai contoh learning spiritual.

"menurut saya, plagiarisme adalah sifat yang harus dijauhi oleh semua orang karena hal tersebut hanya membawa kesenangan semu dan nantinya akan membawa keburukan". (III.3)

“... sebagai mahasiswa harus bertanggung jawab menjalankan peran kita sebagai mahasiswa dengan cara belajar sungguh-sungguh dan diimbangi dengan beribadah yang benar, sehingga ketika kita mendapatkan kesulitan kita tidak akan memikirkan jalan pintas yang akan merugikan diri kita sendiri". (III.42)

Film plagiarisme sebagai trigger dalam penelitian ini, menurut mahasiswa menunjukkan peristiwa yang 
sering terjadi pada pelajar atau mahasiswa sekarang ini. Mereka dengan mudahnya mengcopypaste baik dari internet maupun pekerjaan temannya dalam menyelesaikan tugasnya. Hal ini menunjukkan degradasi moral bagi pelakunya, karena plagiarisme merupakan perbuatan berbohong, curang, mencuri atau menyontek hasil karya orang lain dan film ini memberikan pelajaran atau pesan terhadap pentingnya nilai kejujuran bagi mahasiswa.

Tindak plagiat dilakukan karena kurangnya tanggung jawab dan komitmen, sehingga tugas tidak dapat diselesaikan pada waktunya. Selain itu, kemalasan, kelalaian dan tidak bisa mengatur waktu dengan baik menyebabkan persiapan yang kurang kemudian putus asa dalam penyelesaian tugas skripsi, sehingga akhirnya mengambil jalan pintas dengan mengcopypaste hasil karya orang lain. Akibat tindak plagiat ini akhirnya mahasiswa mendapatkan sanksi DO sebagai konsekuensi perbuatannya dan hukuman ini menimbulkan penyesalan kemudian.

Dalam film ini, satu mahasiswa melakukan tindak plagiat karena malas, meremehkan, lalai, kurangnya tanggung jawab terhadap tugas dan mahasiswa lain karena kuliah sambil bekerja dan tidak bisa mengatur waktu, sehingga sampai pada batas waktu yang ditentukan atau deadline mengambil jalan pintas dengan mengcopy paste hasil karya orang lain. Akibat perbuatan plagiat tersebut mahasiswa akhirnya terkena sanksi yang berat. Maksud awalnya ingin meringankan beban orangtua dengan segera menyelesaikan KTInya dan lulus, akhirnya berbuah penyesalan.

Pembelajaran dengan trigger film pada pendidikan dokter telah dilakukan oleh beberapa peneliti sebelumnya antara lain Ber \& Alroy, ${ }^{18}$ Lumlertgul et al., ${ }^{19}$ Ketis \& Kersnik, ${ }^{20}$ dan Darbyshire \& Baker, ${ }^{21}$ secara umum film atau cinema menarik, menyenangkan dan membantu meningkatkan pemahaman mahasiswa. Penelitian dengan trigger film dapat untuk mengajarkan baik kognitif, psikomotor maupun afektif atau sikap. Pada penelitian ini trigger film digunakan untuk mengajarkan domain afektif atau sikap. Pembelajaran trigger film dikombinasi dengan diskusi kelompok dan refleksi.
Dari hasil analisis kualitatif refleksi mahasiswa menunjukkan bahwa menyontek, melakukan tindak plagiat dengan alasan apapun merupakan perbuatan yang tidak baik. Mereka menyatakan bahwa memplagiat hasil karya orang lain adalah perbuatan curang, mencuri, melanggar aturan, dilarang oleh agama, bahkan kriminal dan menunjukkan degradasi moral pelakunya. Mahasiswa yang melakukan tindakan plagiat ataupun menyontek sudah sepantasnya mendapatkan sanksi yang tegas atau surat drop out (DO). Sanksi yang tegas perlu diberikan sebagai pelajaran atau konsekuensi perbuatan melanggar ketentuan dan menunjukkan sistem penilaian yang jelas dari fakultas dalam pembelajaran PP secara formal.

Perbuatan menyontek maupun plagiat dilakukan karena kurangnya tanggung jawab mahasiswa, sehingga meremehkan terhadap kewajiban dan tugasnya, sering tidak hadir kuliah atau membolos, bermalas-malasan, tidak bisa mengatur waktu antara tugas dan bermain atau antara tugas pokok dengan aktivitas yang lain. Selain itu, juga kurang menghargai saran atau nasihat teman atau orang lain, akibatnya waktu ujian atau dikejar deadline tugas skripsi, mengambil jalan pintas dengan menyontek dan menjiplak hasil pekerjaan teman atau orang lain.

Menurut Mayville, ${ }^{17}$ cheating merupakan tindakan yang diambil dari berbagai alternatif solusi dalam mangatasi situasi. Keputusan untuk melakukan cheating dipengaruhi oleh pandangan atau keyakinan dan orientasi etika seseorang. Situasi yang dapat memicu kejadian cheating antara lain stres karena tugas, sehingga cheating dilakukan sebagai cara praktis untuk menyelesaikannya. Faktor sosial seperti teman yang menyontek dan tidak mendapatkan sanksi dapat mendorong juga terjadinya cheating. Selain itu, juga mahasiswa yang merasa tidak memiliki kewajiban terhadap tugas lebih cenderung melakukan cheating daripada mahasiswa yang mempunyai rasa memiliki terhadap tugas dan tanggung jawab.

Pada refleksi tentang cheating, didapatkan beberapa makna atau kategori yaitu: learning value, learning approach, student preparedness, examination strategy, learning spiritual dan study plan. Hubungan antara 
kategori-kategori tersebut adalah bahwa seseorang dengan kemampuan memaknai suatu peristiwa dan dapat mengambil nilai positif atau dengan kata lain memiliki learning spiritual dan learning value yang baik akan mempunyai perencanaan belajar (study plan) yang baik pula, sehingga dapat memilih strategi menghadapi ujian (examination strategy) yang tepat untuk meraih keberhasilan dan menghindari perbuatan tercela seperti menyontek.

Hasil refleksi mahasiswa tentang plagiarisme didapatkan beberapa kategori makna, yaitu: learning value, plagiarism, study plan, dan learning spiritual. Hubungan antara kategori-kategori tersebut adalah bahwa seseorang dengan kemampuan learning value dan learning spiritual yang baik terhadap peristiwa dan kejadian yang dialaminya akan memberikan pengaruh pada study plan yang positif, sehingga mahasiswa akan lebih bersungguh-sungguh dalam belajar, persiapan dalam menyelesaikan tugasnya, beribadah, berdoa kepada Allah, SWT dan menghargai hasil karya orang lain, sehingga terhindar dari berbagai bentuk tindak plagiat.

Plagiarisme termasuk dalam kategori cheating. Plagiarisme dapat diartikan sebagai the act of putting the forth of the words and ideas of others as one's own original work. Plagiarisme merupakan perbuatan ilegal karena melanggar hak cipta, baik disengaja maupun tidak. ${ }^{17}$ Menurut Cameron et al., ${ }^{16}$ plagiarisme didefinisikan sebagai as using another author's material or ideas without proper attribution. Terdapat tiga tema penting tentang plagiarism, yaitu: 1) an agregious infraction, dideskripsikan sebagai kriminal dan pencurian; 2) tidak adanya niat plagiat bukan suatu faktor mitigasi dan 3) trivial error, seperti bentuk sitasi atau muddled wording dapat disebut sebagai plagiarisme. Berkaitan dengan tindak plagiat ada satu hal yang berpengaruh yang namanya patchwriting yaitu kurangnya pemahaman tentang plagiarisme dan strategi penggunaan pendukung bahasa (linguistic support). Patchwriting cenderung mendorong seseorang khususnya nonnative speakers writing untuk menggunakan secara salah sumber-sumber atau material dalam bahasa Inggris dalam penulisan ilmiah. Dengan demikian, maka perlu dipahami dengan benar cara atau metode sitasi untuk penulisan ilmiah agar terhindar dari plagiarisme terutama bila sumber atau referensinya berasal dari luar atau bahasa Inggris. Dalam penelitian ini faktor pemahaman tentang plagiarisme tidak menjadikan masalah bagi mahasiswa, dalam arti bahwa mereka memahami kalau tindak plagiat sebetulnya merupakan tindakan yang salah dan sudah sepantasnya mendapatkan hukuman yang berat.

Plagiarisme sebagai salah satu bentuk dishonesty dalam pendidikan berkorelasi positif dengan kemajuan sistem teknologi informasi dan lebih merupakan masalah etik dan perilaku. ${ }^{6}$ Ditinjau dari hubungan antara etika dan cheating ada dua pendekatan, yaitu deontological approach dan teleological approach atau utilitarianism. Menurut deontological approach, yang menekankan pada duty dan obligation bahwa cheating itu salah, karena tidak memenuhi duty dan obligation terhadap kejujuran, trust, fairness dan keadilan. Teleological approach atau utilitarianism menekankan pada perbuatan benar atau salah didasarkan pada akibat atau konsekuensi yang ditimbulkannya. Menurut pendekatan ini, cheating itu salah karena tidak memicu kebaikan tetapi justru sebaliknya berpotensi menimbulkan kerugian atau harmful bagi orang lain atau masyarakat. ${ }^{18}$

Academic disintegrity atau academic dishonesty merupakan problem yang perlu mendapatkan perhatian besar fakultas kedokteran dan diperlukan strategi atau policy yang tegas dan efektif untuk mencegah hal ini agar meluluskan dokter atau profesional yang lebih baik. ${ }^{22}$ Cheating tidak mungkin atau sulit untuk dihilangkan atau dieradikasi. Cheating merupakan fenomena yang kompleks terkait dengan keyakinan atau pandangan dan etik seseorang serta disebabkan oleh kondisi yang bervariasi, maka untuk mengurangi prevalensinya perlu kombinasi beberapa strategi. ${ }^{17}$

Budaya kejujuran perlu diciptakan dengan menjunjung tinggi kejujuran dan menjadikan cheating sebagai perilaku yang tidak dapat dibenarkan. Kejujuran diangkat sebagai salah satu topik penting dalam diskusi, pembelajaran dan aturan-aturan dalam berbagai setting pembelajaran. Menekankan bahwa cheating merupakan hal yang salah dan yang terbukti melakukan cheating perlu 
mendapatkan sanksi. Mahasiswa berbuat cheating karena tidak ada aturan, ada aturan tetapi mahasiswa tidak memahami, ada aturan tetapi tidak dipatuhi oleh mahasiswa, staf ataupun petugas.

Mahasiswa akan berbuat cheating bila ada kesempatan atau tidak akan ketahuan. Oleh karena itu, strategi konvensional dengan menegaskan sebelum ujian tentang tata tertib dan larangan serta konsekuensi cheating dalam ujian perlu dilakukan. Strategi yang modern seperti web cam, antiplagiarism soft ware perlu disiapkan untuk mendeteksi dan mengurangi kejadian cheating dan plagiarism menggunakan teknologi canggih seperti handphone, kamera, internet, keylogger, dll.

Memberikan pemahaman dan bimbingan mahasiswa melalui diskusi, tugas, paper dengan lebih menekankan pada prosesnya. Memonitor cara berpikir, cara menulis, catatan atau draft yang dimiliki atau dibuat oleh mahasiswa, sehingga tindakan cheating atau plagiarism dapat dihindari. Menciptakan rasa memiliki untuk mengurangi cheating melalui diskusi, kerja kelompok dan kolaborasi. Mengurangi stres karena tugas juga dapat menurunkan prevalensi cheating dengan cara memberikan tugas yang lebih realistis, dapat dikerjakan dari segi waktu oleh mahasiswa. Komunikasi dan informasi yang jelas tentang akibat dan konsekuensi cheating dan plagiarism dari fakultas kepada mahasiswa pada waktu ujian atau riset. Role model dalam hal integritas akademik dan pemberian constructive feedback juga diperlukan dalam mengurangi kejadian cheating.

Solusi lain untuk mendukung kejujuran akademik selain meningkatkan komitmen civitas akademik adalah merevisi nilai dan tujuan dalam pendidikan tinggi, perbaikan kualitas praktik pembelajaran dan sistem penilaian, memberikan kesempatan yang cukup dalam pembelajaran, memberikan dukungan terhadap semua komunitas akademik dalam institusi atau universitas, menetapkan strategi yang efektif serta menggunakan penghargaan akademik dalam proses pendidikan. ${ }^{23,24}$

Film altruisme sebagai trigger pembelajaran, menggambarkan tokoh dalam film, yaitu dokter Rahma merupakan pribadi yang altruis dan profesional. Hasil refleksi mahasiswa tentang film tersebut menunjukkan situasi yang dilematis, sulit dan langka namun suatu ketika mungkin saja mereka akan dihadapkan pada kondisi seperti itu. Mahasiswa menyatakan bahwa dokter Rahma menunjukkan sikap profesional, di tengah kesulitan yang sedang dihadapinya dia tidak menunjukkan kesedihan bahkan ketenangan ketika melayani pasien. Ia berjiwa altruis, mendahulukan kepentingan menolong pasiennya daripada kepentingan pribadi atau pulang kampung meskipun ayahnya sakit keras. Selain itu, dia mampu berkomunikasi dengan baik, ramah, perhatian baik dengan pasien maupun petugas kesehatan lain. Dokter Rahma mempunyai tekad yang kuat, tanggung jawab yang besar terhadap tugasnya dan semangat pengabdian yang tinggi karena didorong masa lalunya. Ibunya meninggal karena tidak adanya tenaga kesehatan di desanya, sehingga terlambat mendapatkan pertolongan waktu melahirkan adiknya. Dia mendapatkan beasiswa selama pendidikannya dan mempunyai skills atau keterampilan yang baik sebagai dokter muda dan hal ini menunjukkan bahwa dokter Rahma seorang yang pintar. Perilaku yang digambarkan dalam film merupakan sikap dan perilaku yang harus dimiliki oleh seorang profesional dan pantas diteladani.

Hasil refleksi mahasiswa tentang altruisme didapatkan beberapa kategori makna, yaitu: learning value, altruism, learning spiritual, future plan. Hubungan antara kategori-kategori tersebut adalah bahwa, seseorang dengan kemampuan memaknai suatu peristiwa dan dapat mengambil nilai positif atau memiliki learning spiritual dan learning value yang baik akan mempunyai perencanaan ke depan (future plan) yang baik pula untuk menjadi dokter yang altruis dan profesional dalam situasi apapun.

Menurut Leontopoulou cit. Macaulay \& Berkowitz, ${ }^{25}$ sekarang ini altruisme dimasukkan sebagai kategori prosocial behavior, "carried out to benefit another without anticipation of rewards from external sources" altruisme yang berhubungan erat dengan empati merupakan kebalikan atau lawan dari egoisme. Altruisme dan empati dapat dilatihkan baik pada anak maupun orang dewasa pada masa seseorang mencari identitas diri dalam 
kehidupannya. Seseorang dapat mengembangkan sifat altruis secara natural melalui proses pencarian identitas tersebut.

Menurut social learning theory, bahwa prosocial behavior pada anak dibangun berdasarkan standar moral yang ada di lingkungan. Anakanak cenderung menirukan perilaku role model, khususnya orangtua, saudara dan guru sekolah. Riset menunjukkan bahwa anak yang melihat orang lain dengan sikap altruis atau prosocial behaviors, akan cenderung mudah memberi dan menolong orang lain. ${ }^{25}$ Peristiwa di film, yang mengandung pesan altruisme dilandasi dengan aspek religi yang kuat, merupakan paparan pengalaman (environment) bagi mahasiswa dan tokoh di film, dokter Rahma sebagai model yang altruis diharapkan dapat mempengaruhi persepsi dan pikiran mahasiswa (personal) untuk menirukan sikap dan perilakunya seperti di film (behavior). Hasil refleksi mahasiswa menunjukkan, film altruisme bermanfaat sebagai pembelajaran karena dapat memberikan motivasi dan inspirasi bagi mereka dan tokoh dokter muda yang altruis di film patut dijadikan model atau contoh.

\section{KESIMPULAN}

Hasil analisis kualitatif refleksi cheating, altruism dan plagiarism mahasiswa menunjukkan Seseorang dengan kemampuan memaknai suatu peristiwa dan dapat mengambil nilai positif atau memiliki learning spiritual dan learning value yang baik akan mempunyai perencanaan belajar (study plan) yang baik pula, sehingga dapat memilih strategi menghadapi ujian (examination strategy) yang tepat untuk meraih keberhasilan dan menghindari perbuatan tercela seperti cheating atau menyontek. Seseorang dengan learning spiritual dan learning value yang baik terhadap peristiwa dilematis dan sulit akan termotivasi dan tersentuh emosinya, sehingga dalam future plannya akan berusaha menjadi dokter yang altruis dan profesional dalam situasi apapun. Seseorang dengan kemampuan learning value dan learning spiritual yang baik akan memberikan pengaruh pada study plan yang positif, yaitu lebih bersungguh-sungguh dalam berusaha dan berdoa kepada Allah, SWT serta mampu menghargai hasil karya orang lain, sehingga terhindar dari berbagai bentuk tindak plagiat.

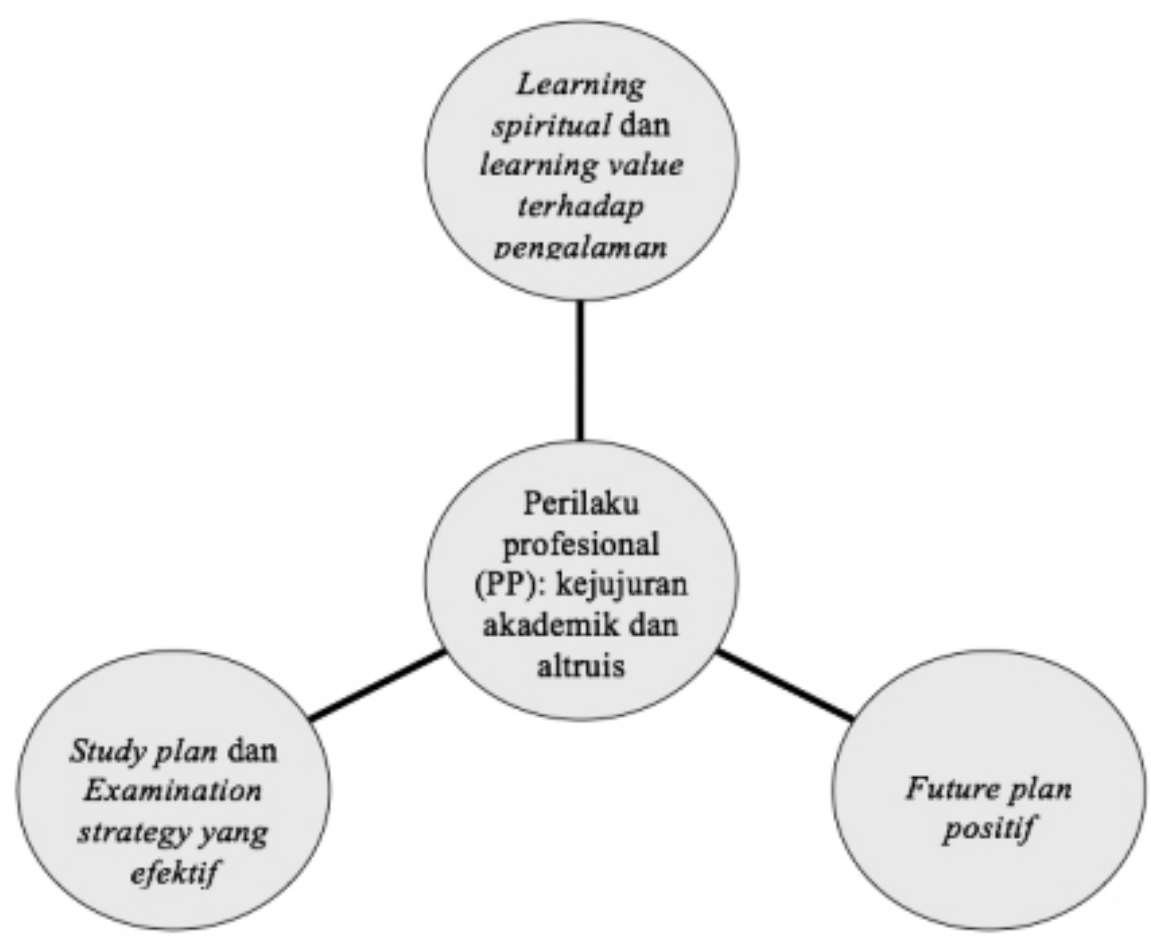

Gambar 2. Diagram pembelajaran perilaku profesional (PP) 


\section{DAFTAR PUSTAKA}

1. Wagner P, Hendrich J, Moseley G, Hudson Vl. Defining Medical Professionalism: A Qualitative Study. Medical Education, 2007;41:288-94.

2. Hays R. Teaching and Learning in Clinical Settings. Radcliffe Publishing Ltd; 2006.

3. Luijk. Teaching and assessment of professional behavior; 2005.

4. Cohen R. Assessing Professional Behaviour and Medical Error. Medical Teacher, 2001;23(2):145 51.

5. Korszun A, Winterburn PJ, Sweetl H, Jones LT, Houston H. Assessment of Professional Afektif and Conduct in Medical Undergraduates. Medical Teacher, 2005;27(8):704-8.

6. Nonis S, Swift CO. An Examination of The Relationship Between Academic Dyshonesty and Workplace Dishonesty: A Multicampus Investigation. Journal of Education for Business. 2001;77(2):69-77.

7. Harper MG. High Tech Cheating. Nurse Education Today, 2006;26:672-9.

8. Kusumawati W. Profesionalisme dan professional behavior mahasiswa FKIK UMY. Mutiara Medika, 2011;11(1):37-45.

9. Erhamwilda. Mencermati Problem Pendidikan Indonesia Untuk Memperbaiki Kualitas Pendidikan (Suatu Upaya Meningkatkan SDM Bangsa). LKTI Dosen. Mimbar Unisba, 2004;20(4):1-24.

10. Patton MQ. Qualitative Research \& Evaluation Methods $3^{\mathrm{Ed}}$. London: Sage publications, Inc; 2002.

11. Cresswell JW. Research design qualitative \& quantitative approaches. London: Sage publications, Inc; 1994.

12. Goldie J, Dowie AT, Cotton P, Morrison J. Teaching professionalism in the early of a medical curriculum: a qualitative study. Medical Education, 2007;(41):610-7.

13. Savitri TP. Strategi Analisis Data Kualitatif untuk Penelitian Pendidikan Kedokteran dan Profesi Kesehatan. Jurnal Pendidikan Kedokteran dan Profesi Kesehatan Indonesia, 2007:2(1):31-5.
14. Silverman D. Interpreting Qualitatif Data $4^{\text {th }}$ Ed. London: Sage Publication Ltd; 2011.

15. KBBHI. Jakarta: Pusat Bahasa Departemen Pendidikan Nasional; 2008.

16. Cameron C, Farver C, Zhao H, McHugh MK. Publication Ethics and the Emerging Scientific Workforce: Understanding "Plagiarism" in a Global Context. Academic Medicine, 2012;87(1):51-4.

17. Mayville KL. Technology, Cheating, Ethics and Strategies for Creating a Culture of Honesty. Journal of Illinois Nursing, 2011;109(3):6-10.

18. Ber R, Alroy G. Teaching Professionalism with The Aid of Trigger Films. Medical Teacher, 2002;24(5):528-31.

19. Lumlertgul N, Kijpaisalratana N, Pityaratstian N, Wangsataruka D. Cinemeducation: A pilot student project using movies to help students learn medical professionalism. Medical Teacher, 2009;31:e32732.

20. Ketis ZK, Kersnik J. Using movies to teach professionalism to medical students. BMC Medical Education, 2011;11: 60.

21. Darbyshire D., Baker D. 2012. A Systematic review and thematic analysis of cinema in medical education. Med Humanit 38: $28-33$.

22. Hejri SM, Wilkes M, Zendehdel K, Asghari F, Fotouhi A, Rashidian A. Academic disintegrity among medical students: a randomized response technique study. Medical Education, 2013;47:14453

23. Hughes JMC, McCabe DL. Understanding Academic Misconduct. The Canadian Journal of Higher Education, 2006;36(1):49-63.

24. Cabe DM. Cheating Why Students Do It and How We Can Help Them Stop; 2006.

25. Leontopoulou S. An Exploratory Study of Altruism in Greek Children: Relations with Empathy, Resilience and Classroom Climate. Psychology, 2010;(5):377-85. 